\title{
Assessment of Cadmium in Maize and Millet of Different District using Canal and Wastewater Irrigation
}

\author{
ZAFAR IQBAL KHAN ${ }^{1 *}$, IFRA SALEEM MALIK ${ }^{1}$, JING MA ${ }^{2}$, FU CHEN ${ }^{2}$, \\ YONGJUN YANG ${ }^{2}$, KAFEEL AHMAD ${ }^{1}$, KINZA WAJID ${ }^{1}$, HUMAYUN BASHIR ${ }^{1}$, \\ MUHAMMAD NADEEM ${ }^{3}$, ASMA ASHFAQ ${ }^{1}$, MUDASRA MUNIR ${ }^{1}$, ILKER UGULU ${ }^{4}$, \\ YUNUS DOGAN 5 \\ ${ }^{1}$ Department of Botany, University of Sargodha, Sargodha, Pakistan \\ ${ }^{2}$ School of Environment Science and Spatial Informatics, China University of Mining and Technology, Xuzhou, China \\ ${ }^{3}$ Department of Nutrition and Food Technology, University of Sargodha, Sargodha, Pakistan \\ ${ }^{4}$ Faculty of Education, Usak University, Usak, Turkey \\ ${ }^{5}$ Buca Faculty of Education, Dokuz Eylul University, Izmir, Turkey
}

\begin{abstract}
The article is focused on concentration of cadmium in maize and millet collected in 20182019 from different district (Sargodha, Faisalabad, Sheikhupura, Lahore and Kasur) of Punjab under different irrigation sources Canal and wastewater. The values of Bioconcentration factor, Translocation factor, Pollution load index, Daily intake of metal, Health Risk Index and Enrichment factor were studied to evaluate the effect of heavy metal accumulation on grains quality and human health. Most of the metals observed in wastewater were present in high amount. Cd concentration increased considerably under wastewater irrigation in soil (1.06 $\mathrm{mg} / \mathrm{kg}$ ) and grains $(1.05 \mathrm{mg} / \mathrm{kg}) . \mathrm{Cd}$ showed highest bioconcentration $(3.82 \mathrm{mg} / \mathrm{kg})$ in canal water. Wastewater irrigated soil exhibited the maximum Pollution Load Index (PLI) values as compared to control treatment. Under the influence of wastewater irrigation, Cd concentration increased considerably in soil and grains. The purpose of study is the labeling of Maize and Millets species of the area according to their toxicity/desirability for use as human food and fodder.
\end{abstract}

Keywords: irrigation, bio concentration, translocation, pollution load index, Maize

\section{Introduction}

Irrigation of the crops which is carried out by the wastewater affects the crops and soil properties negatively. It induces the amount of toxic chemicals in the crops and imbalance the nutrients consequently leads toward the toxicities in crops and causes harmful effect on consumers [1, 2]. Human activities also play an important role in the heavy metal contaminations [3,4]. Anthropogenic activities in collaboration with the nature affects to increase the heavy metal adversely affects the life by different ways [5].

Crops cultivated by the wastewater contain different types of nutrients some are beneficial to grow crops but also contain very harmful substances involving heavy metal such as chromium, lead, cadmium, and nickel which ultimately accumulated in environment and lead to damaging effects in living beings [6].

The momentous toxicity is produced by heavy metals in any form [7]. Among the prevalent cereals Maize (Zea mays) is of significant importance as it provides the source of food and protein for human and animals in several ways. It is used for maize grains and silage for animals to use for food. Maize is also used for industrial purpose to make the fuel. High yield of maize can be obtained without compromising the quality of the crops by using the treated wastewater. The crops which were irrigated with the wastewater give the better result and the yield and the quality was also increased $[8,9]$.

*email: zafar.khan@uos.pk 
Agricultural activities are confined in areas where water is in sufficient amount, scarcity of water inhibit the agriculture. To overcome the demand of water and to meet the requirement of food for the population, farmers are using the wastewater to meet the water deficiency. Wastewater is undone by the treatment plant to enhance the food quality and safety and reduce the water pollution [10].

Many health complications arise due to the penetrating metal absorptions in soil which are captivated by the rising plants resulting in food chain contamination [11]. It was revealed by different studies that the crops which were grown by the wastewater absorb the heavy metal to such an extent that their amount grows higher than the prescribed limit affecting the consumers hazardously [12]. The aim of study is to determine the concentration of heavy metals in water, soil, plants (maize and millet) irrigated with different sources of water.

\section{Materials and methods}

Current research was performed in different districts (Sargodha, Faisalabad, Sheikhupura, Lahore and Kasur) of Punjab during the year 2018-2019. Samples of shoot, grain and soil were gathered from various sites of five districts and made composite sample or one replicate. Four replicates of soil, shoot and grain of maize and millet were collected from different sites in each district. All types of water samples irrigating these grains (canal water and sewage water) $(100 \mathrm{~mL}$ each) were taken from 5 different districts of Punjab. All the samples placed in polypropylene bottles washed with nitric acid (1\%) and later that samples were taken to the research center and stored at $4^{\circ} \mathrm{C}$ until analysis [13].

Total 80 replicates of soil samples from five districts were collected. Samples of soil (one from each corner and one from center of fields) from depth $0-15 \mathrm{~cm}$ were collected from each district. The soil trials were put into constricted bags and conveyed to test center for heavy metals analysis to avoid internal mixing and external contamination. Five composite soil samples were prepared and dried in air, and put in forced air oven for $48 \mathrm{~h}$ at a temperature of $72^{\circ} \mathrm{C}$. These composed samples were dehydrated, kept in categorized wrapped envelopes and kept in incubator for 5 days at a temperature of $70^{\circ} \mathrm{C}$ [14]. Shoot and grain samples of maize and millet were rinsed with condensed water and placed in paper bags. Each sample was assigned identity.

Samples of soil, shoot and grain after aeration were then kept in the oven at temperature of $72^{\circ} \mathrm{C}$ until it becomes completely dried. After taking away from the oven, grains were detached from the shoots and crushed in the pestle and mortar to make powder of it. Each sample weighed $1 \mathrm{~g}$ was used for finding heavy metals. Wet digestion method is used for the breakdown of samples of soil, shoot and grain.

The dried samples were placed in a small conical flask and digested with conc. $\mathrm{HNO}_{3}$ and $\mathrm{H}_{2} \mathrm{O}_{2}$ 1:2 on a hot plate until a colorless solution appear and allowed to cool. After cooling, dilute all the samples in a measuring flask up to $50 \mathrm{~mL}$ as final volume. The samples were then filtered through Whatmann filter paper No. 42. All the processed samples were then passed to Atomic Absorption Spectrophotometer (Perkin-Elmer Corp., 1980) to find the concentration of metal.The Standard solution of was made from the Stock solution, to get the standardize curve.

\subsection{Bio concentration factor}

To found the outcome of transference of metals from soil to plant portions BCF was done by [15]. $\mathrm{BCF}=$ Level of metal in food crop/Level of metal in soil

\subsection{Translocation factor}

Heavy metal have the means of translocation from shoot to grain concentration was calculated by the translocation factor with the resulting formula of [16].

$$
\mathrm{TF}=\frac{\text { Mean conc in grain }}{\text { Mean conc in shoot }}
$$

where Mc is concentration of selected heavy metal. 


\subsection{Pollution load index}

PLI is calculated by the method given by [17].

$$
\text { Pollution Load Index }=\frac{(\mathrm{M}) \mathrm{IS}}{(\mathrm{M}) \mathrm{RS}}
$$

where,

(M)IS = Concentration of metal $(\mathrm{mg} / \mathrm{kg})$ in investigated soil

(M)RS= Reference value of metal in soil

\subsection{Enrichment factor}

EF is calculated by formula of Buat-Menard \&Chesselet [18].

$$
\text { Enrichment factor }(\mathrm{EF})=\frac{(\text { Conc. of metal in plant/Conc. of metal in soil }) \text { sample }}{(\text { Conc. of metal in plant/Conc. of metal in soil }) \text { standard }}
$$

\subsection{Daily intake of metals}

The (DIM) was calculated as given by Sajjad et al. [19].

Daily intake of metal $(\mathrm{DIM})=$ Cmetal $\times$ Cfactor $\times$ Dfood intake $/$ Baverage weight

where Cmetal, Cfactor,Dfood intake and Baverage weight are concentration of heavy metals (mg/kg) daily intake of maize and millet grains (kg person/day) and normal body weight correspondingly. The conversion factor 0.085 was used to convert fresh green weight to dehydrated weight as given by Rattan et al. [20].The DIM by consumption of maize and millet was $0.242 \mathrm{~kg}$ individual /day as given by Wang et al. [21] and average body weight $55.9 \mathrm{~kg}$ was specified by Wang et al. [22].

\subsection{Health Risk Index}

HRI is defined as the proportion of daily intake of metals in the food crop to oral reference dose (RfD) and was calculated with the formula [23].

\subsection{Health risk index $(H R I)=D I M / R f D$}

DIM = Daily intake of heavy metal

RfD $=$ Oral reference dose

An HRI > 1.0 for any single metal indicates that the health of consumer population is at risk or it is carcinogenic [23].

\section{Results and discussions}

\subsection{Water}

ANOVA of Cadmium for water show significant effect in Irrigation source, District and Irrigation source $\mathrm{x}$ District but showed non-significant variation in Forage, Irrigation source $\mathrm{x}$ Forage, District $\mathrm{x}$

\begin{tabular}{|c|c|c|c|c|c|}
\hline \multirow{2}{*}{$\begin{array}{c}\text { Irrigation source of } \\
\text { variation }\end{array}$} & \multirow{2}{*}{$\begin{array}{l}\text { Degree of } \\
\text { freedom }\end{array}$} & \multicolumn{4}{|c|}{ Mean squares } \\
\hline & & Water & Soil & Shoot & Forages \\
\hline Irrigation source & 1 & $50.080^{* * * *}$ & $5.382^{* * *}$ & $5.356^{* * *}$ & $5.518^{* * *}$ \\
\hline District & 4 & $4.835^{* * *}$ & $0.484^{* * *}$ & $0.513^{* * * *}$ & $0.284^{* * *}$ \\
\hline Forage & 1 & $0.777^{\mathrm{ns}}$ & $0.076^{\mathrm{ns}}$ & $0.186^{* * * *}$ & $0.354^{* * *}$ \\
\hline $\begin{array}{l}\text { Irrigation source } \mathrm{x} \\
\text { District }\end{array}$ & 4 & $6.902^{* * *}$ & $0.105^{\text {*** }}$ & $0.164^{* * * *}$ & $0.164^{* * *}$ \\
\hline
\end{tabular}
Forage, Irrigation source x District x Forage (Table 1).

Table 1. Analysis of variance of cadmium in water, soil shoot and grain of Maize and Millet of different districts 


\begin{tabular}{|c|c|c|c|c|c|}
\hline $\begin{array}{c}\text { Irrigation source } x \\
\text { Forage }\end{array}$ & 1 & $0.627^{\mathrm{ns}}$ & $0.109^{*}$ & $0.126^{* * *}$ & $0.127^{* *}$ \\
\hline District x Forage & 4 & $0.634^{\mathrm{ns}}$ & $0.116^{* *}$ & $0.135^{* * *}$ & $0.117^{* * *}$ \\
\hline $\begin{array}{l}\text { Irrigation source } x \\
\text { District } x \text { Forage }\end{array}$ & 4 & $0.765^{\mathrm{ns}}$ & $0.034^{\mathrm{ns}}$ & $0.039^{* * * *}$ & $0.079^{* *}$ \\
\hline Error & 60 & 1.184 & 0.028 & 0.010 & 0.022 \\
\hline
\end{tabular}

Water in different districts in forages ranged from 0.26-3.9. Minimum level of cadmium in water was present in maize of Faisalabad irrigated with canal water, while maximum level of cadmium was present in maize of Sargodha irrigated with wastewater. The heavy metals absorption in canal water and wastewater varied significantly (Table 2, Figure 1).

Table 2. Mean Concentration of Cadmium (mg/L) in water and different parts of Forages $(\mathrm{mg} / \mathrm{kg})$

\begin{tabular}{|ccccccc|}
\hline $\begin{array}{c}\text { Irrigation } \\
\text { Sources }\end{array}$ & District & Forages & Water & Soil & Shoot & Grain \\
& & Maize & 0.35 & 0.06375 & 0.1 & 0.24375 \\
& Sargodha & Millet & 0.3 & 0.1525 & 0.2575 & 0.3575 \\
& & Maize & 0.2625 & 0.17 & 0.14375 & 0.17375 \\
& Faisalabad & Millet & 0.435 & 0.185 & 0.19875 & 0.16 \\
& & Maize & 0.3425 & 0.2225 & 0.3275 & 0.1375 \\
& Sheikhupura & Millet & 0.31875 & 0.25 & 0.305 & 0.205 \\
& & Maize & 0.7875 & 0.3875 & 0.41 & 0.24375 \\
& Lahore & Millet & 0.565 & 0.30625 & 0.34125 & 0.28125 \\
& & Maize & 0.615 & 0.365 & 0.3075 & 0.2675 \\
& \multirow{4}{*}{ Kanal } & Millet & 0.83875 & 0.255 & 0.2725 & 0.32875 \\
& & Maize & 3.90375 & 0.22625 & 0.2175 & 0.2575 \\
& Sargodha & Millet & 3.955 & 0.76375 & 0.88625 & 1.005 \\
& & Maize & 1.44 & 0.41375 & 0.3825 & 0.42375 \\
& Faisalabad & Millet & 0.613875 & 0.585 & 0.51875 & 0.48875 \\
& & Maize & 1.905125 & 0.69875 & 0.7875 & 0.78125 \\
& Sheikhupura & Millet & 3.22125 & 0.84625 & 0.855 & 0.8425 \\
& & Maize & 1.06 & 1.03375 & 1.02875 & 0.78 \\
& \multirow{2}{*}{ Lahore } & Millet & 1.5425 & 1.015 & 1.02625 & 0.98875 \\
& & Maize & 1.075 & 1.06125 & 1.06375 & 1.05125 \\
& Kasur & Millet & 1.9225 & 0.90125 & 1.0725 & 1.0325 \\
\hline
\end{tabular}

The range of cadmium (0.38- 0.44) was greater than our values according to Khan et al. [24]. The level of cadmium in current findings was greater given by NEQS [25] and it was $0.01 \mathrm{mg} / \mathrm{L}$. All water samples (sewage water and canal water) showed the higher concentration of cadmium than its permissible limit. Heavy metals are transported from the mud to the plant plus the cob and are likely health problems to humans and animals feeding upon them. The Cadmium has higher mobility and absorbing capacity hence it is easily absorbed by plant and translocate toward upper parts of plant [26]. 


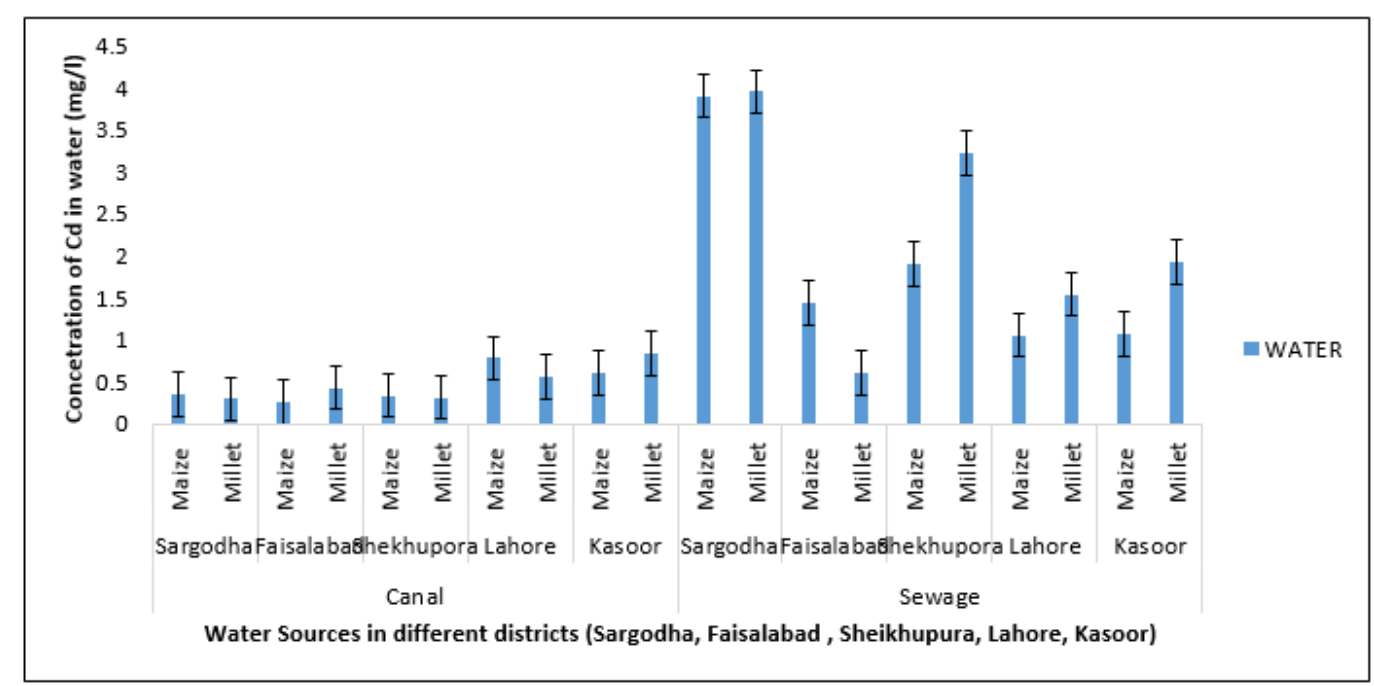

Figure 1. Mean Concentration of Cadmium in water of different districts $(\mathrm{mg} / \mathrm{L})$

\subsection{Soil}

ANOVA of Cadmium for soil show significant effect in Irrigation source, District and Irrigation source x District but showed non-significant variation in Forage, Irrigation source x District x Forage. Significant and least significant effect was show in Irrigation source $\mathrm{x}$ Forage and District $\mathrm{x}$ Forage (Table 1). Absorption of Cadmium in mud ranges from 0.063-1.06. Maize of Kasur irrigated with wastewater has high level of cadmium while the minimum concentration was present in the maize of Sargodha irrigated with canal water (Table 2, Figure 2).

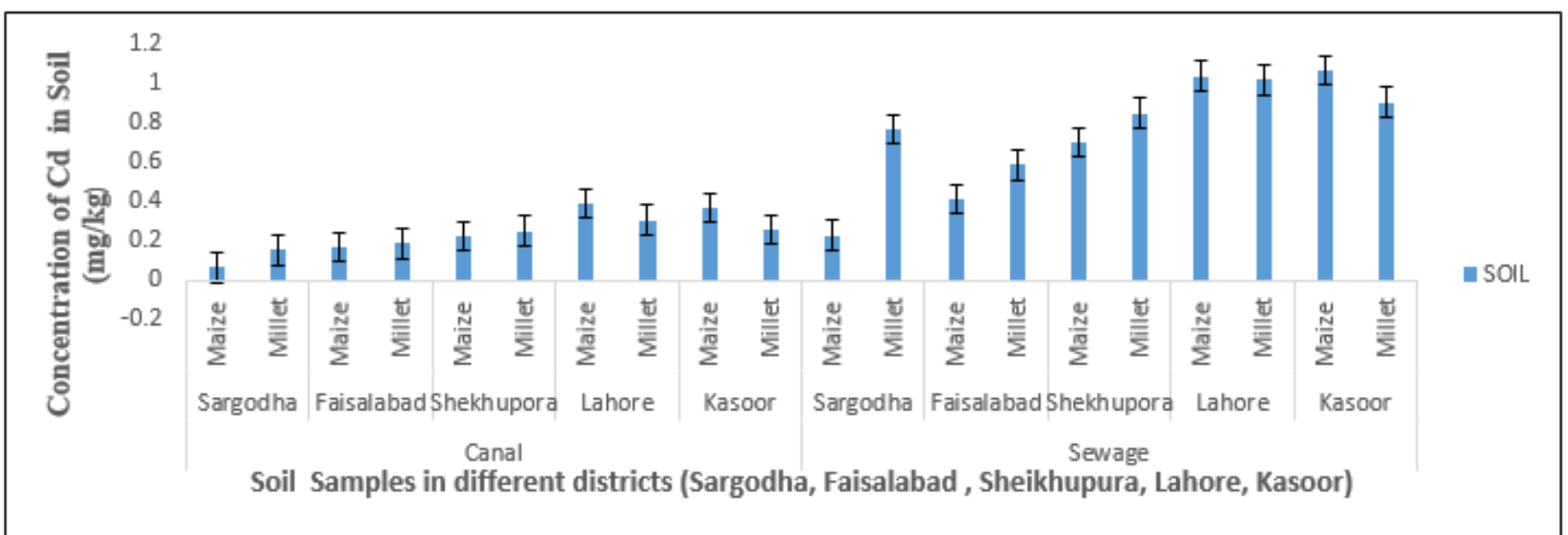

Figure 2. Mean Concentration of Cadmium in soil of different districts (mg/kg)

The persistent wastewater irrigation caused many-fold increase in absorption of contaminants in the soil. In wastewater moistened soil, the Cd absorption was $1.06 \mathrm{mg} / \mathrm{kg}$ which was more than those of the permissible limits of WHO [27]. The value of Cd was higher to present value that is $2.8 \mathrm{mg} / \mathrm{kg}$ proposed by Hassan et al. [28].The amount of Cd was lesser that was $0.20 \mathrm{mg} / \mathrm{kg}$ given by Rattan et al. [20] as compared to present study. Geochemically Cd was relatively movable element in soil and it was easily taken up by plants.

\subsection{Shoot}

Analysis of variance of Cadmium for shoot show significant effect in Irrigation source, District, Forage, Irrigation source $x$ District, Irrigation source $x$ Forage, District $x$ Forage, Irrigation source $x$ 
District x Forage (Table 1). The mean concentration of cadmium in shoot fluctuated from 0.1- 1.07. The maximum value was found in millet of Kasur and minimum was found in maize of Sargodha irrigated with canal water (Table 2, Figure 3).

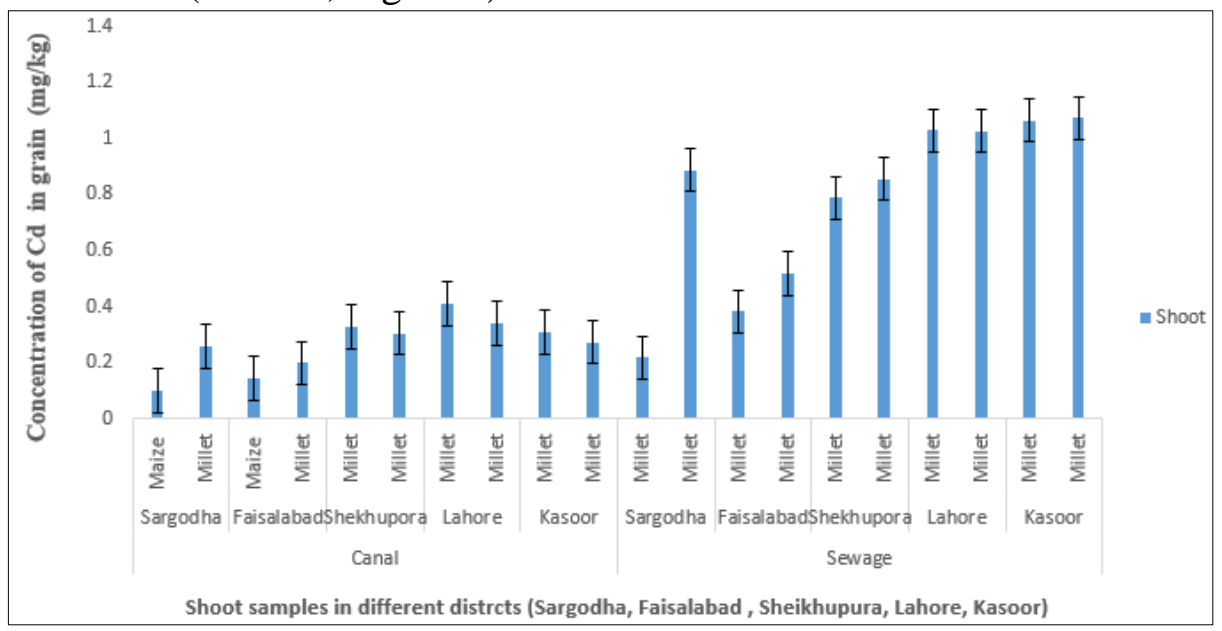

Figure 3. Mean Concentration of Cadmium in shoot of different districts $(\mathrm{mg} / \mathrm{kg})$

Cadmium was accumulated in shoot also. Our outcomes were comparable to the conclusions of Farhat et al. [29]. The present study values also exceed the PML of Codex Alimentarius Commission [30]. The reason of high concentration of cadmium in sewage water irrigated maize plants was due to the presence of higher concentration of $\mathrm{Cd}$ in water. Earlier studies completed by Mapanda et al. [31] on vegetables showing increasing attentions of heavy metals (cadmium, zinc, copper, lead, chromium and nickel) in soils irrigated with wastewater for ten years. There is therefore necessity for threatening peoples about harmful effects of metals later some of these metals such as $\mathrm{Cr}, \mathrm{Cd}$ and $\mathrm{Pb}$ are considered risky impurities that can gather in the human body, with a moderately long half-life.

\subsection{Grain}

Analysis of variance of Cadmium for grain show significant effect in Irrigation source, District, Forage, Irrigation source $x$ District and least significant effect in Irrigation source $x$ Forage, Irrigation source $x$ District $x$ Forage (Table 1). The cadmium varied from 0.13-1.05 in grain. Higher value was present in forages grown in sewage water of maize of Kasur while lower value was found in maize of Sheikupura irrigated with canal water (Table 2, Figure 4).

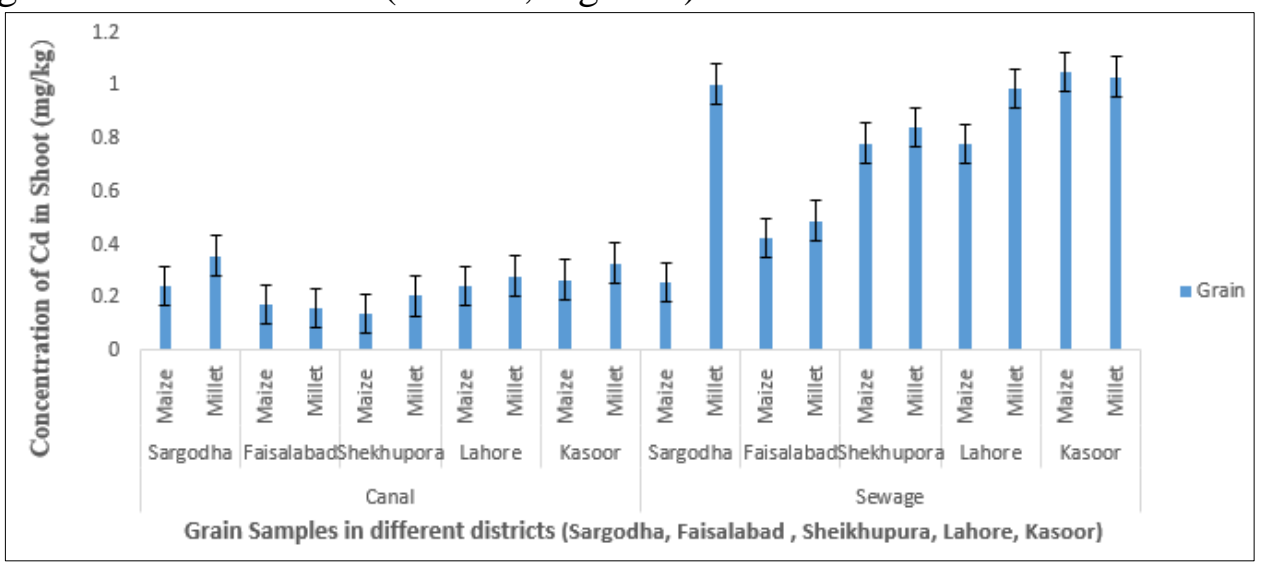

Figure 4. Mean Concentration of Cadmium in grain of different districts (mg/kg)

These values of cadmium were higher than the range $(0.002$ to $0.004 \mathrm{mg} / \mathrm{kg}$ ) reported by Edem et al. [32]. The main absorbing structure in plants is through roots and then it is transferred into the edible 
portions of plants that is leaves, fruits and seeds. It collects in animal milk and flashy tissues. Phosphate compost also added Cadmium into the soil is of the concern heavy metal. Its transfer from soil to the eatable portions of farming food yields is significantly larger than other contamination elements. Cadmium also may be damaging to soil bacterial populations [28]. In current study the value of cadmium was higher as compared to value $0.062 \mathrm{mg} / \mathrm{kg}$ given by $\mathrm{Yu}$ et al. [33]. The concentration of Cadmium exceeded the Permissible limits of of $0.4 \mathrm{mg} / \mathrm{kg}$ proposed by Codex Alimentarius Commission [30].

\subsection{Bio concentration factor}

$\mathrm{BCF}$ for cadmium transmission from soil to grain varies from 0.61 to $3.82 \mathrm{mg} / \mathrm{kg}$ (Table 3, Figure 5). Highest and lowest content was present in maize of Sargodha and Sheikhupura irrigated with canal water. (FigureCurrent findings of $\mathrm{BCF}$ for $\mathrm{Cd}$ in all samples were lower as compared to that given by Asdeo [34]. Our findings were greater than Khan et al. [2]. Lokeshwari and Chandrappa [35] defined that $\mathrm{Cd}$ is supplementary transportable than other heavy metals hence it fixes less strongly to soil.

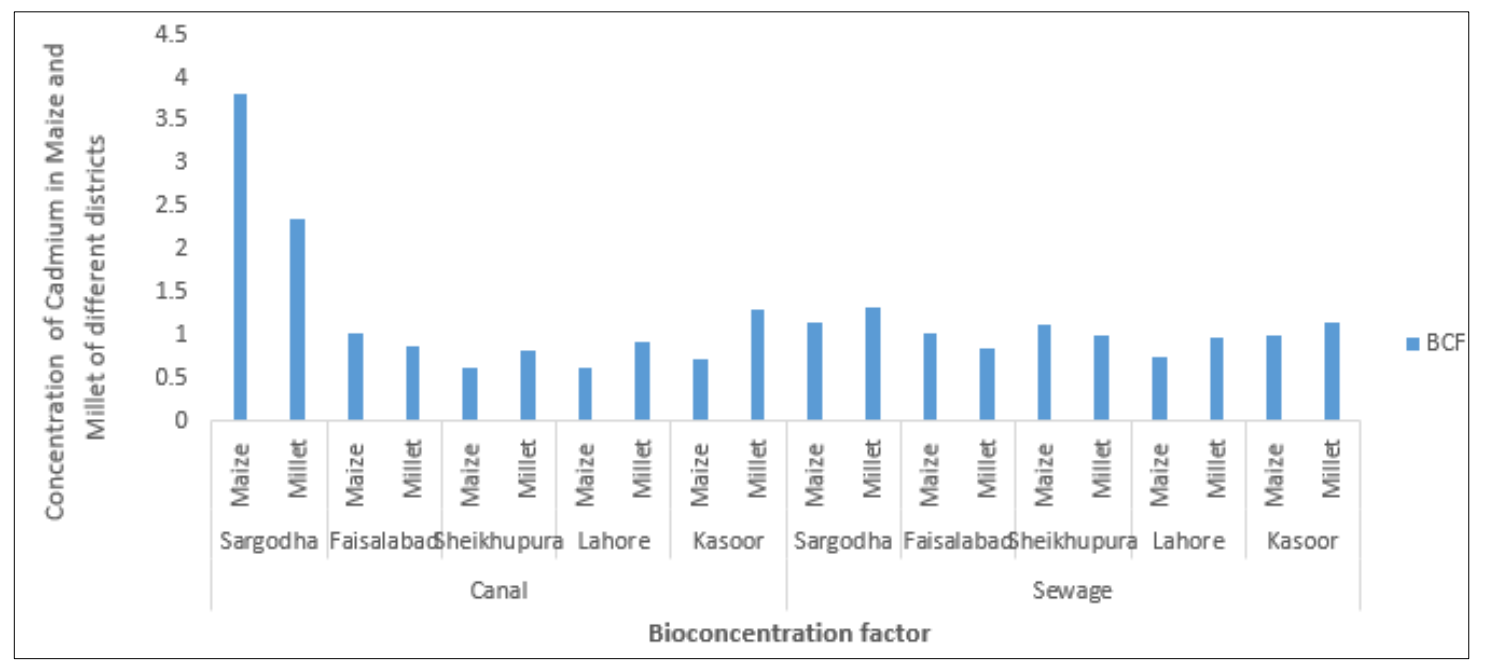

Figure 5. Bio concentration factor of Cadmium in Maize and Millet of different districts

\subsection{Translocation factor}

The ability of the plants to move and accumulate the heavy metals from one part to the other part is determined through translocation factor [36], which it is calculated as the ratio of heavy metal content of one part to the other. Translocation factor is a key component to determine the exposure of human to metals via food chain. Translocation factor of cadmium from shoot to grain varies from 0.41 to 2.43 (Table 3, Figure 6). Highest concentration was found in maize of Sargodha and lowest was observed in maize of Sheikhupura irrigated with canal water. Asdeo [34] reported the lower translocation factor values for $\mathrm{Cd}$ in relation to our study. Lokeshwari and Chandrappa [35] have investigated that $\mathrm{Cd}$ is not strongly bound by soil and therefore it is easily uptake by the plants. 


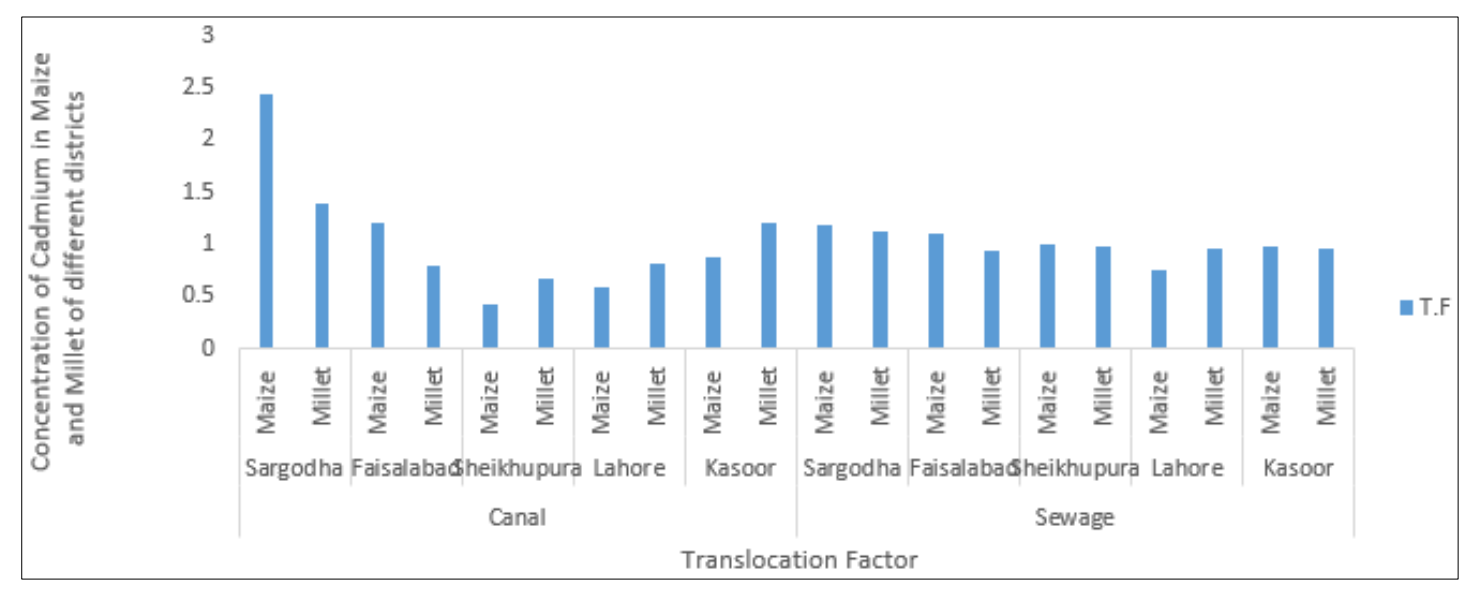

Figure 6. Translocation factor of Cadmium in Maize and Millet of different districts

\subsection{Pollution load index}

Pollution severity of soil is well estimated by determining pollution load index. The PLI for cadmium in different districts fluctuated from 0.042 to 0.712 (Table 3, Figure 7). The extreme concentration was noticed in maize of Kasur irrigated with wastewater while low content was noticed in maize of Sargodha in canal water. The pollution in soil was discovered using method Pollution load index [37]. This method gives an easy and relative source for calculating the different irrigation systems. Tomlinson et al. [38] explained that if value comes in zero that this shows no harm, however if value comes in one and greater than one than it would be harmful. In the present study the PLI was higher than that of Khan et al. [2].

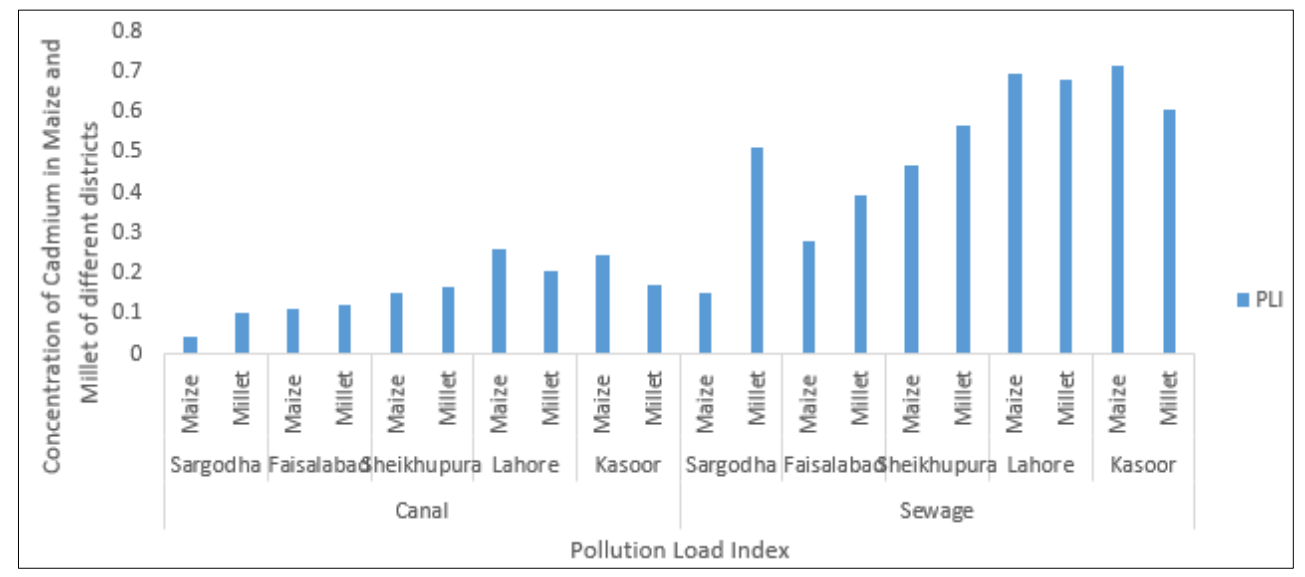

Figure 7. Pollution Load Index of Cadmium in Maize and Millet of different districts

\subsection{Daily intake of metal}

The values of DIM for cadmium fluctuated from 0.00059 to 0.0045 (Table 3, Figure 8). 


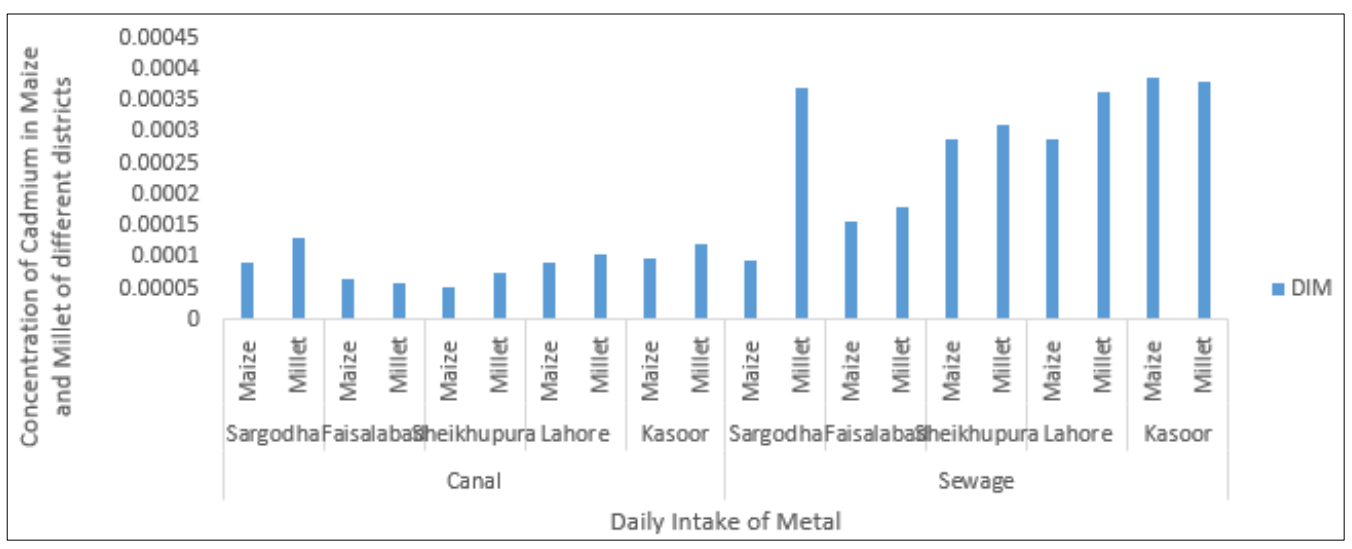

Figure 8. Daily Intake of Metal of Cadmium in Maize and Millet of different districts

Highest and lowest concentration was found in maize of Kasur and Sheikhupura irrigated by wastewater and canal water. The values of daily intake of metals for $\mathrm{Cd}$, was lower as related to tolerable daily intake limit $(0.07 \mathrm{mg} / \mathrm{kg})$ by USEPA [23]. The daily intake of metals depends on equally the metal attention in crops and the amount of consumption of the particular food crop. Daily intake of Cd for all types of samples was found much lower than the findings $(0.001 \mathrm{mg} / \mathrm{kg} / \mathrm{day})$ of Chaoua et al. [39]. Khan et al. [2] suggested the higher Daily intake $(0.01,0.01 \mathrm{mg} / \mathrm{kg} / \mathrm{day})$ for Cd. Wang et al. [22] had given the lower Daily intake $(0.0002 \mathrm{mg} / \mathrm{kg} /$ day $)$ for Cd. Daily intake rate for Cd investigated in the present research for all types of samples were below than the maximum tolerable limit (0.07 mg/kg/day) suggested by USEPA [23]. Radwan and Salama [40] have also reported the same results that there is no risk caused by the consumption of wastewater irrigated wheat grains.

\subsection{Health risk index}

The range of HRI for Cd via intake of grains in various districts of different forages was 0.59-4.55 $\mathrm{mg} / \mathrm{kg}$ (Table 3, Figure 9). Maximum and minimum value was found in Maize of Kasur and Sheikhupura using irrigation of waste water and canal water. HRI value for Cd (5.86) given by Singh et al. [41] was higher than the range of current investigation. Wheat is known as an important way of dietary exposure to heavy metals. However, features of metals and high-risk areas are other important sources of heavy metal exposure. Due to this reason, potential health risk associated with heavy metals might be different as compared to present estimation [42].

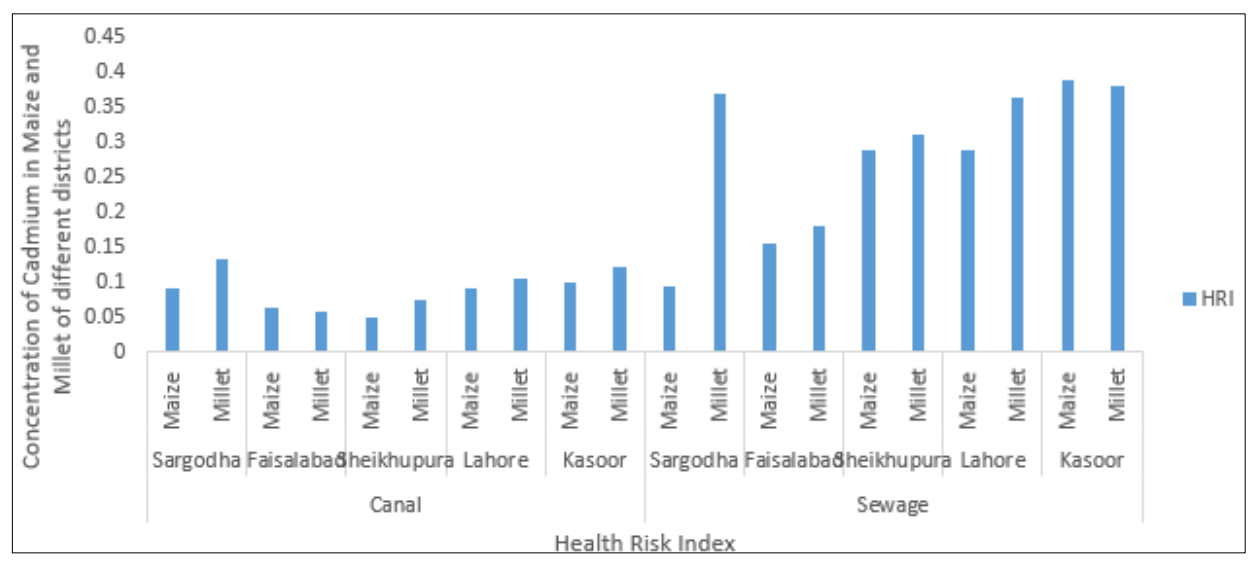

Figure 9. Health risk Index of Cadmium in Maize and Millet of different districts 


\subsection{Enrichment factor}

The Enrichment factor of cadmium in different districts varied from 4.6-28.4 mg/kg (Table 3, Figure 10). Highest value of EF is recorded in maize of Sargodha watered with stream water and lowest in maize of Sheikhupura watered with canal water. Alghobar and Suresha [43] investigated the lower EF value (1.50) for Cd. All the samples in present research had the higher Enrichment factor value than that value (4.57), which was given by Singh et al. [41]. Higher value of EF for Cd showed its lower retention in the soil and high mobility.

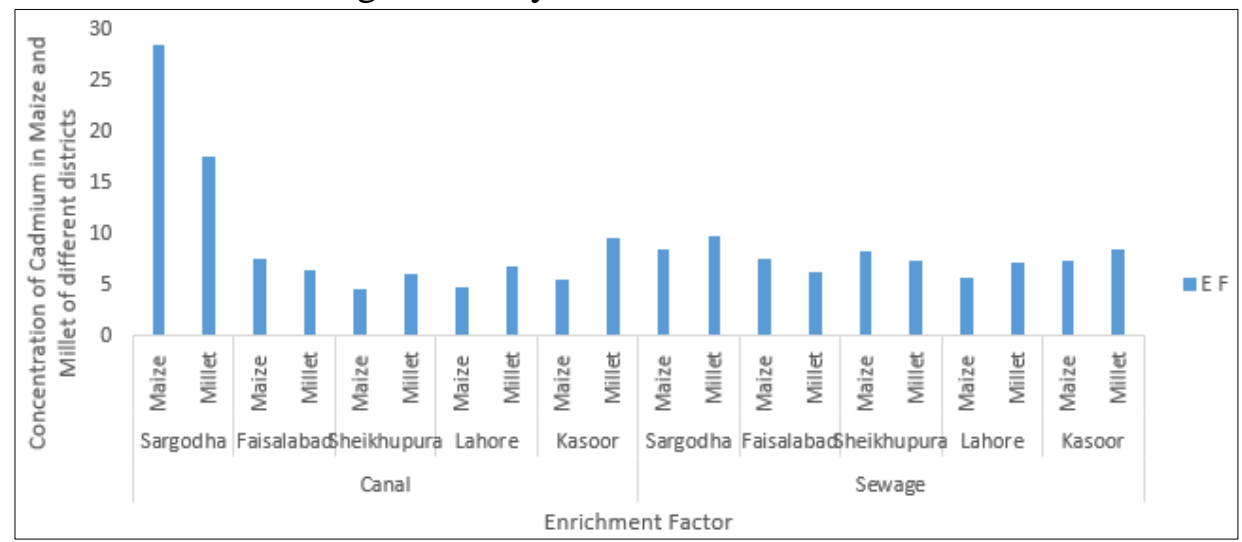

Figure 10. Enrichment factor of Cadmium in Maize and Millet of different districts

Table 3. BCF, TF, PLI, DIM, HRI and EF of Cadmium in Maize and Millet of different districts

\begin{tabular}{|c|c|c|c|c|c|c|c|c|}
\hline \multirow[t]{10}{*}{ Source } & District & & BCF & $\mathbf{T} \mathbf{F}$ & P L I & DIM & HRI & $\mathbf{E F}$ \\
\hline & & Maize & 3.823529 & 2.4375 & 0.042785 & 0.001055 & 1.055233 & 28.48529 \\
\hline & Sargodha & Millet & 2.344262 & 1.38835 & 0.102349 & 0.001548 & 1.547674 & 17.46475 \\
\hline & & Maize & 1.022059 & 1.208696 & 0.114094 & 0.000752 & 0.752191 & 7.614338 \\
\hline & Faisalabad & Millet & 0.864865 & 0.805031 & 0.124161 & 0.000693 & 0.692665 & 6.443243 \\
\hline & & Maize & 0.617978 & 0.419847 & 0.149329 & 0.000595 & 0.595259 & 4.603933 \\
\hline & Sheikhupura & Millet & 0.82 & 0.672131 & 0.167785 & 0.000887 & 0.887478 & 6.109 \\
\hline & & Maize & 0.629032 & 0.594512 & 0.260067 & 0.001055 & 1.055233 & 4.68629 \\
\hline & Lahore & Millet & 0.918367 & 0.824176 & 0.205537 & 0.001218 & 1.217576 & 6.841837 \\
\hline & & Maize & 0.732877 & 0.869919 & 0.244966 & 0.001158 & 1.15805 & 5.459932 \\
\hline \multirow[t]{10}{*}{ Canal } & Kasoor & Millet & 1.289216 & 1.206422 & 0.171141 & 0.001423 & 1.423211 & 9.604657 \\
\hline & & Maize & 1.138122 & 1.183908 & 0.151846 & 0.001115 & 1.114758 & 8.479006 \\
\hline & Sargodha & Millet & 1.315876 & 1.133992 & 0.512584 & 0.004351 & 4.350805 & 9.803273 \\
\hline & & Maize & 1.024169 & 1.107843 & 0.277685 & 0.001834 & 1.834481 & 7.63006 \\
\hline & Faisalabad & Millet & 0.83547 & 0.942169 & 0.392617 & 0.002116 & 2.115877 & 6.224252 \\
\hline & & Maize & 1.118068 & 0.992063 & 0.46896 & 0.003382 & 3.382156 & 8.329606 \\
\hline & Sheikhupura & Millet & 0.995569 & 0.98538 & 0.567953 & 0.003647 & 3.647317 & 7.416987 \\
\hline & & Maize & 0.754534 & 0.758202 & 0.693792 & 0.003377 & 3.376744 & 5.621282 \\
\hline & Lahore & Millet & 0.974138 & 0.963459 & 0.681208 & 0.00428 & 4.280456 & 7.257328 \\
\hline & & Maize & 0.990577 & 0.988249 & 0.712248 & 0.004551 & 4.551029 & 7.3798 \\
\hline Sewage & Kasoor & Millet & 1.145631 & 0.962704 & 0.604866 & 0.00447 & 4.469857 & 8.534951 \\
\hline
\end{tabular}




\section{Conclusions}

Current results showed the $\mathrm{Cd}$ concentration in water, soil, maize and millet were above the permissible limits. As heavy metals concentration were lower in the crop but long term wastewater irrigation can accumulate heavy metals in the edible parts of crops leading to serious health risks causing (Cancer, Hepatitis etc.) via food chain. The highest transfer factor was seen in Cd for shoot and grain Cd showed the highest DIM value of present analysis resulting in contamination of the soil. Current research suggest that regular monitoring of municipal wastewater discharge and treatment must be carried out in order to avoid heavy metals toxicity in the soil and plants growing there.

Acknowledgements: The third author Dr. Kafeel Ahmad is thankful to university of Sargodha, Punjab, Pakistan for the financial support through a research project titled "Assessment of Heavy metals in Millet and Maize Irrigated with Different Sources of Water: A Case Study in Different Districts of Punjab".

\section{References}

1.MUCHUWETI, M., BIRKETT, J., CHINYANGA, W.E., ZVAUYA, R., SCRIMSHAW, M.D., Heavy metal content of vegetables irrigated with mixture of wastewater and sewage sludge in Zimbabwe: implications for human health. Agri. Eco. Environ., 112, 2006, 41-48.

2. KHAN Z.I., IQBAL, S., BATOOL, F., AHMAD, K., ELSHIKH, M.S., AL SAHLI, A., EL-ZAIDY, M., BASHIR, H., NOORKA, I.R., SHER, M., MUNEEB, A., Evaluation of heavy metals uptake by wheat growing in sewage irrigated soil: relationship with heavy metal in soil and wheat grains. Frese. Envir. Bullet., 26, 2017a, 7838-7848.

3. DOGAN, I., OZYIGIT I.I., DEMIR, G., Influence of aluminium on mineral nutrient uptake and accumulation in Urticapilulifera L. J. of Plant Nutrit., 37, 2014, 469-481.

4.UGULU, I., UNVER, M.C., DOGAN, Y., Determination and comparison of heavy metal accumulation level of Ficuscarica bark and leaf samples in Artvin, Turkey. Oxida Communi., 39, 2016, 765-775.

5. UNVER, M.C., UGULU, I., DURKAN, N., BASLAR, S., DOGAN, Y., Heavy metal contents of Malvasylvestris sold as edible greens in the local markets of Izmir. Ekolo., 24, 2015, 13-25.

6.SHAHID, M., DUMAT, C., POURRUT, B., ABBAS, G., SHAHID, N., PINELLI, E., Role of metal speciation in lead-induced oxidative stress to roots. Russi. Jour. of Plant Physiol., 62, 2015, 448-454.

7.DINU, C., UNGUREANU, E.M., VASILE, G.G., KIM, L., IONESCU, I., ENE, C., SIMION, M., Soil and Vegetation Pollution from an Abandoned Mining Area Situated in Hunedoara Country, Romania, Rev. Chim., 69(1), 2018, 14-20.

8.MOUSAVI, S. R., GALAVI, M., ESKANDARI, H., Effects of treated municipal wastewater on fluctuation trend of leaf area index and quality of maize (Zea mays). Wat. Sci. and Technol., 67, 2013, 797-802.

9.ESMAILIYAN, Y., HEIDARI, M., GHANBARI, A., Effect of municipal wastewater with manure and chemical fertilizer on grain yield and yield components in corn (KoSc 704). Jour. of Agron., 7, 2008, 227-280.

10.MOUSAVI, S.R., TAVAKOLI, M.T. DADGAR, M., CHENARI, A.I., MORIDIYAN, A., SHAHSAVARI, M., Reuse of Treated Wastewater for Agricultural Irrigation with Its Quality Approach. Biolog. Foru. Intro. Journ., 7, 2015, 814-822.

11.CAUNII1, A., NEGREA, A., PENTEA, M., SAMFIRA, I., MOTOC, M., BUTNARIU, M., Mobility of Heavy Metals from Soil in the Two Species of the Aromatic Plants. Rev. Chim., 66(3), 2015, 382-386.

12.CHUNG, B.Y., SONG, C.H. PARK, B.J. CHO, J.Y., Heavy metals in brown rice(Oryza sativa L.)and soil after long term irrigation of wastewater discharged from domestic sewage treatment plants. Pliedosph., 21, 2011, 621-627 
13.AFNOR, Water Quality and analysis methods, 1997

14.AFNOR, Qualite des sols: recueil de norms francaises Paris-La Defense, 1994

15.CUI, Y. J., ZHU, Y. G., ZHAI, R. H., CHEN, D. Y., HUANG, Y. Z., QUI, Y., LIANG, J. Z., Transfer of metals from near a smelter in Nanjing, China. Environ. Interna., 30, 2004, 785-791.

16.LI, Q., CAI, S., MO, C., CHU, B., PENG, L., YANG, F., Toxic effects of heavy metals and their accumulation in vegetables grown in saline soil. Ecotoxi. Environ. Safe., 73, 2012, 8488.

17.LIU, W., ZHAO, H., OUYANG, J.Z., SODERLUND, Z.Y., LIU, L., Impacts of sewage irrigation on heavy metals distribution and contamination in Beijing, China. Environ. Int., 31, 2005, 805-812.

18.BUAT-MENARD, P., CHESSELET, R., Variable influence of the atmospheric flux on the trace metal chemistry of oceanic suspended matter. Earth and Plane.Sci. Lett., 42, 1979, 399-411.

19.SAJJAD, K., FAROOQ, R., SHAHBAZ, S., KHAN, M. A., SADIQUE, M., Health risk assessment of heavy metals for population via consumption of vegetables. Worl. Appl. Sci. Jourl., 6, 2009, 16021606.

20.RATTAN, R.K., DATTA, S.P., CHHONKAR, P.K., SURIBABU, K., SINGH, A.K., Long-term impact of irrigation with sewage effluents on heavy metal content in soils, crops and groundwater-a case study. Agricul. Ecosys. and Environ., 2005, 310-322

21.WANG, X., HUAN, G.W., TIAN, H.G., DONG, S.R., YIN, H.G., CAO, X.H., Investigation on dietary of urban residents in Tianjin from 2000-2004. Jourl. of Pub. Healt., 23, 2007, p. 1245

22.WANG, X., SATO, T., XING, B., TAO, S., Health risks of heavy metals to the general public in Tianjin, China via consumption of vegetables and fish. Sci of the Tot. Environ., 28, 2005, 350.

23.***USEPA(United State Environmental Protection Agency). 2002. Region 9, Preliminary Remediation Goals

24.KHAN, I. U., KHAN, N.U., KHAN, M.Q., ULLAH, K., BIBI, Z., RAHMAN, H.U., GANGOH, M.S., Prolonged Wastewater Irrigation And Heavy Metal Accumulation In Soils, Vegetables And Fodder Crops. Carpath. Jour. of Eart. and Environ. Scien., 10, 2015, 211 - 221.

25.***NEQS, Ministry of Environment, Local Government and Rural Development, Islamabad Pakistan, 2005, 1920

26.KABATA-PENDIAS, A., Trace elements in soil and plants. Boca Raton, London, New York: CRC Press, 2010

27.***WHO - World Health Organization, Geneva, Switzerland, 1989

28.HASSAN, N.U., MAHMOOD, Q., ISEEM, A., IRSHAD, M., FARIDULLAH, A., PERVEZ, A., Assessment of heavy metals in wheat plants irrigated with contaminated waste water. Polish Jour.l of Environl studi, 22, 2013, 155-12.

29.FARHAT, E. A., GALAL, T.M., ELAWA, O. E., HASSAN, L.M., Health risk assessment and growth characteristics of wheat and maize crops irrigated with contaminated wastewater. Envir. Monit. and Asses., 189, 2017, 535.

30.CODEX ALIMENTARIUS COMMISSION. CODEX, Geneva, Switzerland, 2006

31.MAPANDA J., MANGWAYANA, E.N., NYAMANGAR, J., GILLER, K.E., The effect of longterm irrigation using wastewater on heavy metal contents of soils under vegetables in Harare, Zimbabwe. Agricu. Ecos. Environ., 107, 2005, 151-165.

32.EDEM, C.A., GRACE, I., VINCENT, O., REBECCA, E., MATILDA, O., A Comparative Evaluation Of Heavy Metals In Commercial Wheat Flours Sold In Calabar -Nigeria. Pak. Jour. of Nutrit., 8, 2009, 585-587.

33.YU, X., WANG, Z., LYNN, A., CAI, J., HUANGFU, Y., GENG, Y., TANG, J., ZENG, X., Heavy Metals in wheat grown in Sewage Irrigation: a Distribution and Prediction Model. Polish Jour. of Environ. Studi., 25, 2016, 413-418.

34.ASDEO, A., Toxic Metal Contamination of Staple Crops (Wheat and Millet) in Periurban Area of Western Rajasthan. Intern.Refer. Jour. of Engine. and Scie., 3, 2014, 8-18. 
35.LOKESHWARI, H., CHANDRAPPA, G. T., Impact of heavy metal contamination of Bellandur Lake on soil and cultivated vegetation. Current Science, 91, 2006, 620.

36.BERMUD EZ, G.M., JASAN, S., PLA, R., PIGNATA, M.L., Heavy metal and trace element concentrations in wheat grains: Assessment of potential non-carcinogenic health hazard through their consumption. Journ. of Hazrd. Materi., 193, 2011, 264-271.

37.ANGULO, E., The Tomlinson pollution load index applied to heavy metal Bmussel-watch data: a useful index to assess coastal pollution. Scie. Total Environ., 187, 1996, 19-56.

38.TOMLINSON, L., WILSON, G., HARRIS, R., JEFFREY, D.W., Helgolander Meeresun, 33, 1980, p. $566-575$

39.CHAOUA, S., BOUSSAA, S. GHARMALIAND, A.E., BOUMEZZOUGH, A., Impact of irrigation with wastewater on accumulation of heavy metals in soil and crops in the region of Marrakech in Morocco. Jour. of the Saudi Soci. of Agricult. Scien., 2018, 1-6.

40.RADWAN, M.A., SALAMA, A.K., Market basket survey for some heavy metals in Egyptian fruit and vegetables. Food and Chemi. Toxico., 44,2006, 1273-1278.

41.SINGH, A., SHARMA, R. K., AGRAWAL, M., MARSHALL, F. M., Health risk assessment of heavy metals via dietary intake of food stuffs from the waste water irrigated site of a dry tropical area of India. Food and Chemi. Toxico., 48, 2010, 611-619.

42.SIPTER, E., ROZSA, E., GRUIZ, K., TATRAI, E., MORVAI, V., Sitespecific risk assessment in contaminated vegetable gardens. Chemosp., 71, 2008 1301-1307.

43.ALGHOBAR, M.A. SURESHA, S., Effect of wastewater irrigation on growth and yield of rice crop and uptake and accumulation of nutrient and heavy metals in soil. Appli Ecolol. Environ.Scien., 4, 2016, 53-60.

Manuscript received: 25.03 .2020 